\title{
Butyltin Compounds In vitro Inhibition of Human Platelet Epinephrine-Induced Aggregation and Blockade of Epinephrine Binding to Platelets
}

\author{
Hiroyuki YANAGISAWA and Osamu WADA* \\ Department of Hygiene, School of Medicine, Gunma University, \\ 3-39-22 Showa-machi, Maebashi, Gunma 371, Japan \\ *Department of Hygiene and Preventive Medicine, Faculty of Medicine, \\ University of Tokyo, Hongo, Bunkyo-ku, Tokyo 113, Japan
}

(Received July 1, 1985 and in revised form August 28, 1985)

\begin{abstract}
The effects of mono-, di-, and tributyltin, which are widely used in industry, on human platelet aggregation were studied in vitro. The results demonstrated that these organic butyltin compounds inhibit epinephrine-induced aggregation. The antiaggregating concentrations $\left(\mathrm{IC}_{50}\right)$ of the butyltin compounds were $10 \mathrm{nM}$ for tributyltin, $10 \mu \mathrm{M}$ for dibutyltin and $500 \mu \mathrm{M}$ for monobutyltin. However, none of these compounds affected the platelet aggregation induced by others stimuli (ADP, arachidonate, and collagen). On the other hand, all of the butyltin compounds inhibited the binding of ${ }^{3} \mathrm{H} \mid$-DHEC to human platelets, and di- and tributyltin significantly inhibited the incorporation of $\left|{ }^{14} \mathrm{C}\right|$-epinephrine into gel-filtered platelets. These results indicate that organic butyltin compounds inhibit epinephrine-induced aggregation by blocking the epinephrine binding to human platelets.
\end{abstract}

Key words: Butyltin-Organotin-Alpha-adrenergic antagonist-Epinephrine binding-Platelet aggregation

\section{INTRODUCTION}

Organotin compounds are used in a variety of applications., ${ }^{1,2)}$ They are involved in such widely divergent fields as: 1) stabilizers for polyvinylchloride; 2) industrial and agricultural biocides; 3 ) wood-preserving and anti-fouling agents; and 4) catalytic agents in a variety of industrial processes. This wide use of organotin has led to the extensive study of the toxicology of these compounds. The inhibition of oxidative phosphorylation, ${ }^{3)}$ production of edematous lesions in the white matter of the central nervous system, ${ }^{4)}$ depression of thymusdependent immunity, ${ }^{5,6)}$ and diabetic lipemia,,$^{7-9)}$ are among the biological

Abbreviations: ADP, adenosine diphosphate; DHEC, dihydroergocryptine; HHT, 12 L-hydroxy-5, 8, 10-heptadecatrienoic acid ; HETE, 12-L-hydroxy-5, 8, 10, 14-eicosatetraenoic acid; and TX, thromboxane. 
effects of these agents which have been shown in mammalian systems.

Recent studies in our laboratory have shown that organotins inhibit the stimulus-reaction system of various cells. ${ }^{7,10-12)}$ In this study, we have examined in detail the effects of butyltin, a representative organotin, on stimulus-induced human platelet aggregation in vitro. The results of this study show that butylin compounds inhibit epinephrine-induced human platelet aggregation by blocking epinephrine binding to cell membrane.

\section{Materials AND Methods}

\section{Preparation of platelet-rich plasma}

Blood was collected from six healthy male subjects (mean age, $29 \pm$ S.D. 3 years) who had not received any medication for 4 weeks, using 21-gauge needles and sterile plastic syringes containing sodium citrate as an anticoagulant ( 1 part of $3.8 \%$ sodium citrate to 9 parts of blood). The citrated blood was gently mixed and centrifuged at $180 \times \mathrm{g}$ for $20 \mathrm{~min}$ at $20^{\circ} \mathrm{C}$ and the supernatant (platelet-rich plasma; PRP) was carefully transferred to a plastic tube using a plastic pipette. The platelet concentration of PRP was adjusted to approximately $350,000 / \mu 1$ by the addition of platelet-poor plasma (PPP) prepared by centrifugation of the remainder of the blood at $3000 \times \mathrm{g}$ for $20 \mathrm{~min}$ at $4{ }^{\circ} \mathrm{C}$. Platelet concentration was counted in a platelet counter (Towa Model PL 100, Tokyo, Japan ).

\section{Platelet aggregation}

Platelet aggregation was examined at $37^{\circ} \mathrm{C}$ in a Lumi-Aggregometer (Chrono$\log$ Corp., Havertown, PA) according to the method of Feinman et al. ${ }^{13)} \mathrm{Ag}$ gregation was measured as percentage light transmission, using the light transmission of PRP as $0 \%$ and that of PPP as $100 \%$. Added chemicals consisted of $10 \%$ of the final volume of the assay mixture. L-epinephrine bitartrate (Sigma Chem. Co., St. Louis, MO) was dissolved in saline containing $5 \mathrm{mM} \mathrm{NaHSO}$ and $0.01 \mathrm{~N} \mathrm{HCl}$, and then diluted 100 -fold or more with saline prior to the aggregation assay. Disodium ADP $\left(10^{-2} \mathrm{M}\right)$ was prepared in $100 \mathrm{mM}$ veronal buffer $(\mathrm{pH}$ 6.8) and was further diluted in saline prior to the aggregation assay. Collagen reagent (HORM) was obtained from Hormon-Chemie (München, West Germany), and diluted in HORM buffer. Sodium arachidonate (Sigma) was prepared and kept under nitrogen.

\section{Preparation of solutions of butyltin compounds}

Monobutyltin trichloride, dibutyltin dichloride, and tributyltin chloride were obtained from Sankyo Organosynthesis Co., Ltd. (Kawasaki, Japan). The stock solutions of these butyltin compounds, containing $10^{-1}$ to $10^{-9} \mathrm{moles} / 1$, were prepared by dissolving them in $97 \%$ ethanol. Each solution of these compounds 
was diluted 100-fold with saline just before the experiments. In addition, tin (IV) chloride (Nitto Kasei Co., Ltd. Osaka, Japan) was dissolved in $0.1 \%$ ethanol.

\section{Spectrophotometric analyses}

L-epinephrine bitartrate was dissolved in $50 \mathrm{mM}$ sodium phosphate buffer, $\mathrm{pH}$ 7.4. The stock solutions of butyltin compounds were diluted 100 -fold with $50 \mathrm{mM}$ sodium phosphate buffer, $\mathrm{pH}$ 7.4. After confirming the $\mathrm{pH}$ of the final solutions, epinephrine $\left(10^{-4} \mathrm{M}\right)$ was incubated with either $0.1 \%$ ethanol (control) or $10^{-3} \mathrm{M}$ butyltin compounds at $37^{\circ} \mathrm{C}$ for $30 \mathrm{~min}$. Absorbance and fluorescence spectra were obtained using $0.1 \%$ ethanol in phosphate buffer as the blank. Spectrophotometric measurements were performed on a Hitachi 124 Dual-beam Sepctrometer and a Hitachi Fluorescence Spectrophotometer.

The incorporation of $\left|{ }^{14} \mathrm{C}\right|$-epinephrine into human platelets

DL- $\left|7-{ }^{14} \mathrm{C}\right|$-epinephrine hydrochloride $(48.2 \mathrm{mCi} / \mathrm{m} \mathrm{mol})$ was obtained from New England Nuclear (Boston, USA) and stored at $-20^{\circ} \mathrm{C}$. PRP $\left(3.0 \times 10^{5}\right.$ cells $/ \mu 1$ ) was preincubated with tin (IV) chloride or butyltin compounds at $37^{\circ} \mathrm{C}$ for $15 \mathrm{~min}$. After pre-incubation, $10 \mathrm{nmol}$ or $30 \mathrm{nmol}$ of $\left|{ }^{14} \mathrm{C}\right|$-epinephrine was added to $10 \mathrm{ml} \mathrm{PRP}$, and incubated at $37^{\circ} \mathrm{C}$. Samples of $330 \mu \mathrm{l}$ were transferred at appropriate time intervals into microfuge tubes containing $50 \mu \mathrm{l}$ of $\mathrm{FL}$ 20 silicone oil (Shinetsu Chemical Co., Ltd, Annaka, Japan), and centrifuged for $5 \mathrm{~min}$ in an Eppendorf microfuge (Model 1514, New York, USA). Because the specific gravity of FL 20 silicone oil is the same as that of human platelets, the latter were spun down with the silicone oil. After discarding the supernatant, the platelet fraction containing silicone oil was transferred into the vial of a scintillation counter and the radioactivity was assayed. The radioactivity of the samples without incubation was defined as the nonspecific $\left|{ }^{14} \mathrm{C}\right|$-epinephrine incorporation. The specific incorporations was calculated as total minus nonspecific incorporation. Preliminary experiments showed a linear relationship between the incubation time ( $1 \mathrm{~min}$ to $30 \mathrm{~min}$ ) and the amount of incorporated radioactive epinephrine. Therefore, in the following experiments radioactive epinephrine was incubated with PRP for $1 \mathrm{~min}$.

\section{Preparation of gel-filtered platelets}

Gel filtration of platelets was carried out as reported earlier ${ }^{14)}$ on siliconized glass columns measuring 2.5 by $45 \mathrm{~cm}$ (Pharmacia, Sweden). The columns were equipped with gel-supporting nets having a pore diameter of $40 \mu \mathrm{m}$ and were packed to a height of $25 \mathrm{~cm}$ with Sepharose 2B (Pharmacia, Sweden). The columns were previously equilibrated with $\mathrm{Ca}^{2+}$-free Tyrode's solution containing $1.6 \%$ human serum albumin (Sigma). The PRP was gently layered on top of the gel and eluted with the solutions with which the gel was equilibrated. The most concentrated fractions of gel-filtered platelets appearing in the void volumes were collected. The collected fractions were at once diluted with $\mathrm{Ca}^{2+}$-free 
Tyrode's solution containing $1.6 \%$ human serum albumin and $5 \mathrm{mM}$ HEPES buffer (N-2-hydroxyethyl-piperazine-N'-2-ethane sulfonic acid, Sigma), pH 7.35. After the addition of $\mathrm{CaCl}_{2}$ (final concentration, $4 \mathrm{mM}$ ), an alpha-adrenergic binding study was done as described below.

\section{Alpha-adrenergic binding assays}

Human platelets first aggregate and undergo a release reaction when incubated with catecholamines. Indirect evidence indicates that these events are mediated through alpha-adrenergic receptors. ${ }^{15)}$ We used $\left|{ }^{3} \mathrm{H}\right|$-DHEC, an alpha-adrenergic antagonist, to determine the effects of butyltin compounds on the binding of epinephrine to platelet membrane, because it has been established that DHEC binds to the alpha-adrenergic receptor of human platelets. ${ }^{15,16)}$ Gel-filtered platelets were used in these binding assays. Alpha-adrenergic binding assays were done by the method of Newman et al. ${ }^{16)}$ A one-tenth volume of $\left|{ }^{3} \mathrm{H}\right|$-DHEC taken up in distilled water $(26.2 \mathrm{Ci} / \mathrm{mmole}$, New England Nuclear, Boston, USA) was incubated at $37^{\circ} \mathrm{C}$ with gel-filtered human platelets. Binding reaction was terminated by the addition of $4 \mathrm{ml}$ of buffer, $\mathrm{pH} 7.4$ at $37^{\circ} \mathrm{C}$ containing 10 $\mu \mathrm{M}$ phentolamine (Ciba-Geigy Corp. New Jersey, USA). Samples were then filtered over glass-fiber filters (Whatman GF/C) and washed within 20 seconds with $20 \mathrm{ml}$ of $50 \mathrm{mM}$ Tris- $\mathrm{HCl}$ buffer at $37^{\circ} \mathrm{C}$. Dried filters were then counted in a liquid scintillation system. Nonspecific binding, determined by incubation of platelets with $\left|{ }^{3} \mathrm{H}\right|$-DHEC and $10 \mu \mathrm{M}$ phentolamine, generally amounted to 25 to $40 \%$ of the total bound radioactivity from the labeled substance. Specific $\left|{ }^{3} \mathrm{H}\right|$-DHEC ( 0.5 to $\left.40 \mathrm{nM}\right)$ binding to platelets at $37^{\circ} \mathrm{C}$ reached equilibrium by $30 \mathrm{~min}$. Therefore, all equilibrium binding studies were carried out for 30 $\min$.

\section{Chromatographic separation of arachidonic acid and its metabolites}

Samples of $50 \mathrm{ml}$ of PRP were incubated at $37^{\circ} \mathrm{C}$ for $2 \mathrm{~h}$ with $2 \mu \mathrm{Ci}$ of $\left|{ }^{14} \mathrm{C}\right|$-arachidonic acid $(52.1 \mathrm{mCi} / \mathrm{mmol})$ (Amersham Corp.). At the end of the incubation period, EDTA was added to the medium to make a final concentration of $2 \mathrm{mmol}$, and the platelets were pelleted by centrifugation at $3000 \times \mathrm{g}$ for $20 \mathrm{~min}$ at $4^{\circ} \mathrm{C}$. The pellet was resuspended gently in $50 \mathrm{ml} \mathrm{NaCl} /$ Tris- $\mathrm{HCl}(120$ $\mathrm{mM} / 30 \mathrm{mM}$ ) buffer, $\mathrm{pH} 7.4$ (Tris/ $\mathrm{NaCl}$ buffer).

One-milliliter samples of the labeled platelets $\left(1 \times 10^{9}\right.$ cells $\left./ \mathrm{ml}\right)$ were preincubated with either $0.1 \%$ ethanol (control) or tributyltin chloride $\left(1 \times 10^{-5} \mathrm{M}\right)$ for $15 \mathrm{~min}$ at $37^{\circ} \mathrm{C}$. Collagen or epinephrine was added to give a final concentration of $20 \mu \mathrm{g} / \mathrm{ml}$ or $2 \mu \mathrm{M}$ respectively, and the mixture was incubated at $37^{\circ} \mathrm{C}$ for $5 \mathrm{~min}$. Lipid extraction of the whole incubation mixture was done according to the method of Billah et al. ${ }^{17)}$ Dried lipids were dissolved in chloroform and spotted on silica gel G plates (E.M. Merck, Darmstadt, West Germany).

The solvent used for separation was the upper phase from a mixture of ethylacetate-2, 2, 4-trimethylpentane-acetic acid-water (90:50:20:100, by vol.). 
Radioactive spots were visualized by iodide staining and autoradiography, and the radioactivity in each spot was determined by liquid scintillation counting. Standard HETE, HHT and $\mathrm{TXB}_{2}$ were made available by members of the Experimental Chemistry Unit of the Ono Pharmaceutical Co., Ltd. (Osaka, Japan).

\section{RESUlts}

Effects of tin compounds on human platelet aggregation induced by various stimulants

As shown in Table 1, mono-, di-, and tri-butyltin $(10 \mu \mathrm{M})$ significantly inhibited epinephrine-induced aggregation while these compounds did not have any inhibitory effects on ADP-, collagen-, or arachidonate-induced aggregation. In addition, ADP-, collagen-, and arachidonate-induced aggregation were not inhibited by these butyltin compounds at any concentration up to $500 \mu \mathrm{M}$ (data not shown). Butyltin compounds inhibited epinephrine-induced aggregation in a dose-dependent manner (Fig. 1). Among butyltin compounds tested in this experiment, tributyltin had the strongest inhibitory activity on epinephrine-induced aggregation (Fig. 1). The anti-aggregating concentrations $\left(\mathrm{IC}_{50}\right)$ of butyltin compounds were $10 \mathrm{nM}$ for tributyltin, $10 \mu \mathrm{M}$ for dibutyltin and $500 \mu \mathrm{M}$ for monobutyltin, respectively. Inorganic tin (IV) did not inhibit either epinephrineinduced aggregation or other types of stimulant-induced aggregation at any concentration up to $10^{-3} \mathrm{M}$.

Table 1. Effects of tin compounds on human platelet aggregation induced by various stimulants

\begin{tabular}{|c|c|c|c|c|c|c|c|c|c|}
\hline $\begin{array}{l}\text { Tin com- } \\
\text { pounds } \\
(\mu \mathrm{M})\end{array}$ & & & $\begin{array}{l}\text { Mon } \\
\text { tric }\end{array}$ & de & $\begin{array}{l}\text { Dik } \\
\text { dic }\end{array}$ & & & de & Control \\
\hline Stimulants & 1.0 & 10 & 1.0 & 10 & 1.0 & 10 & 1.0 & 10 & \\
\hline
\end{tabular}

\begin{tabular}{|c|c|c|c|c|c|c|c|c|c|}
\hline $\begin{array}{l}\text { Epine- } \\
\text { phrine } \\
(1 \mu \mathrm{M})\end{array}$ & $75 \pm 5.7$ & $71 \pm 4.1$ & $68 \pm 9.2$ & $58 \pm 2.8^{*}$ & $69 \pm 8.6$ & $48 \pm 4.0^{*}$ & $22 \pm 5.0^{*}$ & $9.5 \pm 2.0^{*}$ & $75 \pm 3.0$ \\
\hline $\begin{array}{l}\text { ADP } \\
(10 \mu \mathrm{M})\end{array}$ & $70 \pm 2.2$ & $72 \pm 3.7$ & $70 \pm 4.5$ & $67 \pm 6.1$ & $70 \pm 5.2$ & $64 \pm 6.9$ & $68 \pm 4.1$ & $68 \pm 4.0$ & $70 \pm 3.2$ \\
\hline $\begin{array}{l}\text { Collagen } \\
(20 \mu \mathrm{g} / \mathrm{m} l)\end{array}$ & $74 \pm 4.1$ & $75 \pm 1.9$ & $75 \pm 4.0$ & $73 \pm 3.0$ & $71 \pm 4.1$ & $75 \pm 3.3$ & $70 \pm 4.2$ & $72 \pm 2.6$ & $75 \pm 2.7$ \\
\hline $\begin{array}{l}\text { Sodium } \\
\text { Arachido- } \\
\text { nate } \\
(1.7 \mathrm{mM})\end{array}$ & $76 \pm 1.5$ & $74 \pm 3.9$ & $73 \pm 2.9$ & $75 \pm 3.1$ & $75 \pm 3.0$ & $72 \pm 2.7$ & $75 \pm 2.1$ & $74 \pm 1.8$ & $76 \pm 4.0$ \\
\hline
\end{tabular}

The extent of aggregation is expressed as percentage light transmission. Values indicate the means \pm S.D. of three or five different experiments performed in PRP preincubated for $15 \mathrm{~min}$ with butyltin compounds and $\mathrm{SnCl}_{4}$. Controls were preincubated with $0.01 \%$ ethanol solution.

* $\mathrm{p}<0.01$, as compared with control. 


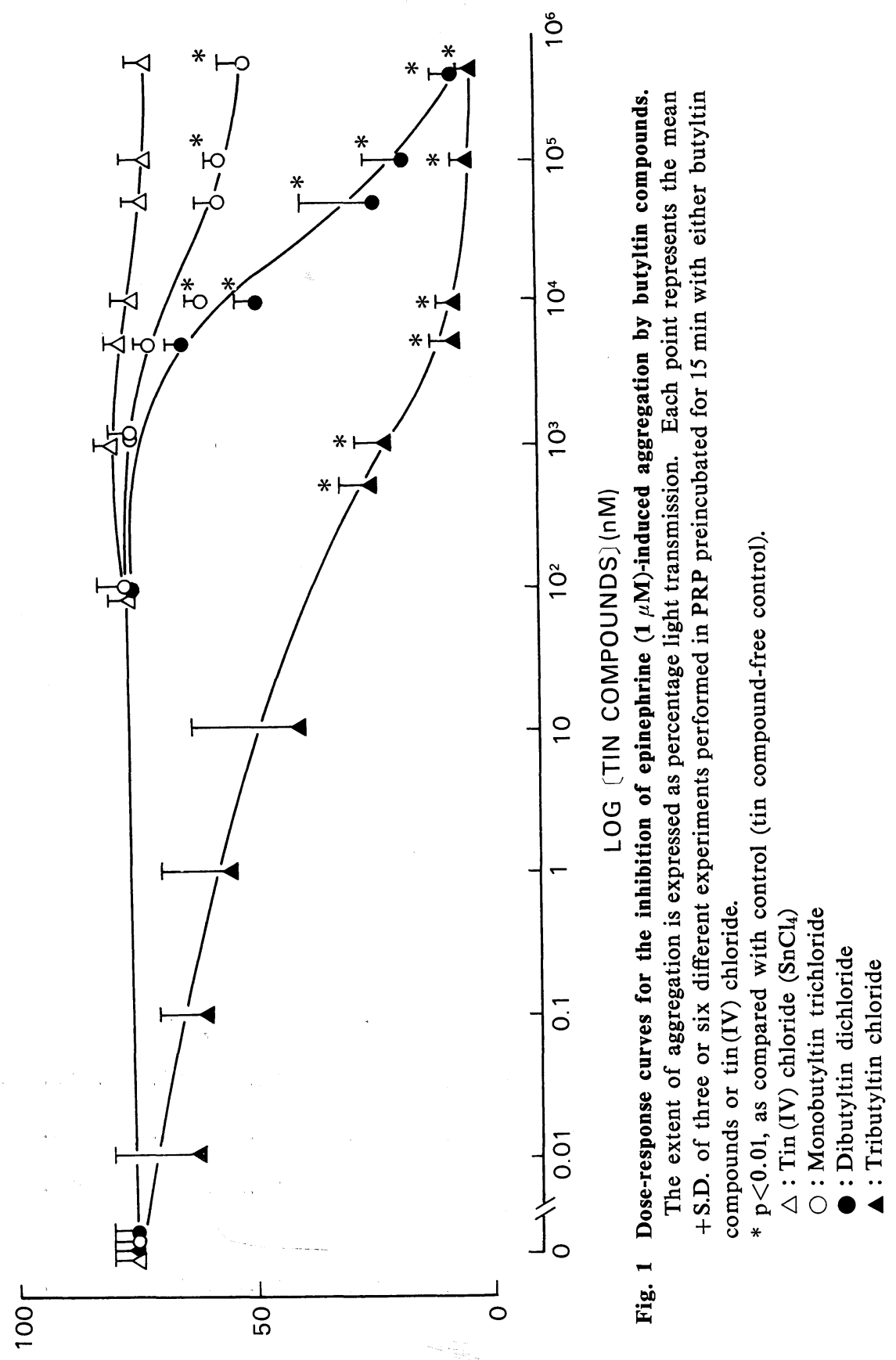

NOISSIWSN $\forall Y \perp \perp H D I 7 \%$ 
Counteractive effect of epinephrine itself against the inhibitory action of butyltin compounds on epinephrine-induced aggregation

PRP was preincubated for $15 \mathrm{~min}$ with either $0.1 \%$ ethanol (control) or butyltin compounds $\left(10^{-5} \mathrm{M}\right)$ and then exposed to various doses of epinephrine. As shown in Fig. 2, epinephrine induced a complete platelet aggregation at a concentration of $1 \mu \mathrm{M}$ in the control. In platelets pretreated with mono-, di-, and tri- butyltin compounds, the aggregating concentration became higher than that of the control. Aggregating concentrations for platelets pretreated with butyltin compounds were approximately $2 \mu \mathrm{M}$ for monobutyltin and approximately $20 \mu \mathrm{M}$ for dibutyltin, respectively. Only 50\% aggregation was seen in tributyltin-treated platelets even when stimulated with $20 \mu \mathrm{M}$ of epinephrine. However, aggregation occurred dose-dependently with increased epinephrine concentrations. These results indicate that epinephrine itself has a counteractive effect against the inhibitory activity of butyltin compounds.

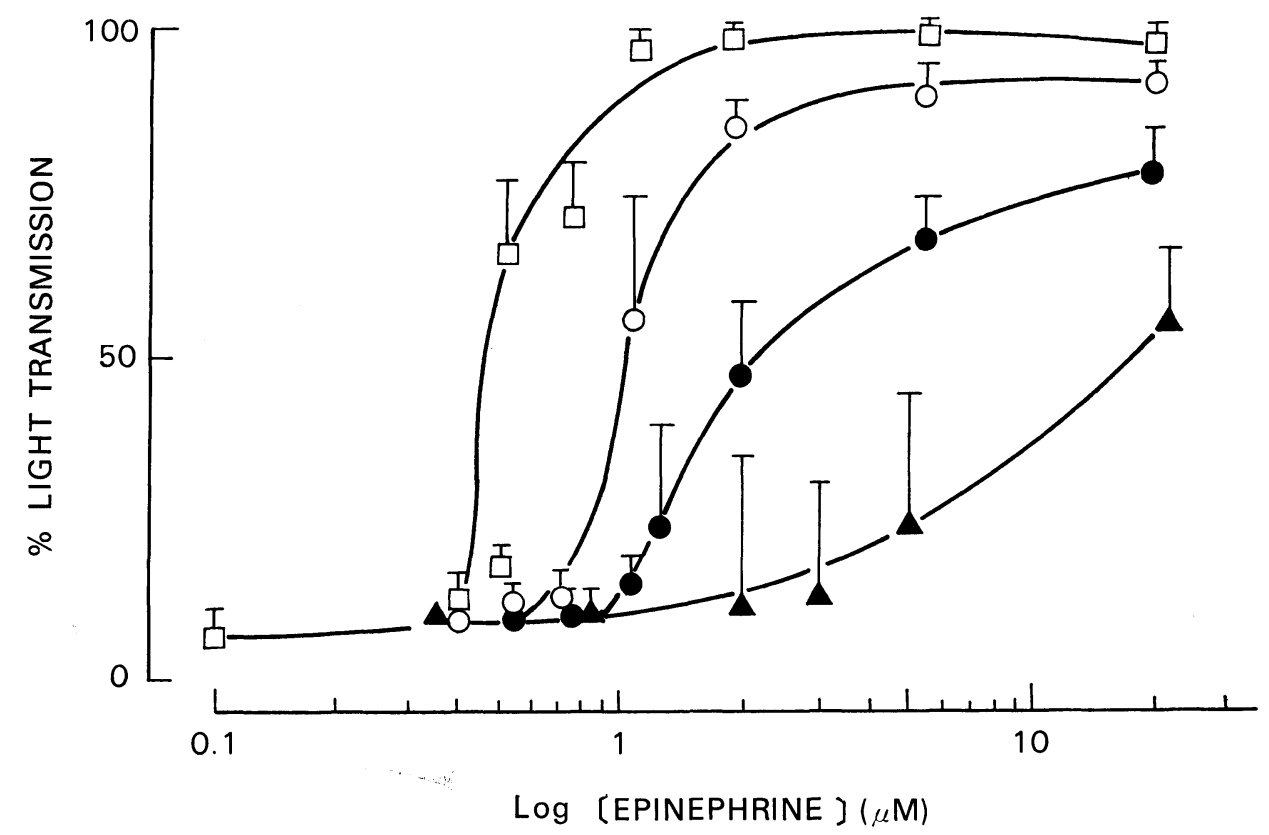

Fig. 2. Counteractivity of epinephrine itself against the inhibitory effects of butyltin compounds on epinephrine-induced aggregation.

Human platelets pretreated with butyltin compounds $(10 \mu \mathrm{M})$ were exposed to various doses of epinephrine. Controls were pretreated with $0.01 \%$ ethanol solution for $15 \mathrm{~min}$ at $37^{\circ} \mathrm{C}$. Each point represents the mean+S.D. of three experiments.

$\square$ : Control

$\bigcirc$ : Monobutyltin trichloride

: Dibutyltin dichloride

$\Delta$ : Tributyltin chloride 
Effects of butyltin compounds on absorbance and fluorescence spectra of epinephrine

Epinephrine $\left(10^{-4} \mathrm{M}\right)$ was incubated with either $0.1 \%$ ethanol (control) or $10^{-3} \mathrm{M}$ tri-, di-, or monobutyltin at $37^{\circ} \mathrm{C}$ for $30 \mathrm{~min}$. Epinephrine (control) had two absorption peaks at $205 \mathrm{~nm}$ and $279 \mathrm{~nm}$ at $\mathrm{pH} 7.4$ before incubation. After incubation, there was no difference between the absorbance spectrum of the control and that of epinephrine incubated with butyltin compounds. Also, no new peaks were detected (data not shown). In addition fluorometric analyses showed that the fluorescence spectrum of epinephrine was not changed by incubation with butyltin compounds $\left(10^{-3} \mathrm{M}\right)$ (data not shown). These results suggest that epinephrine is not destroyed by butyltin compounds, and also that no epinephrine-butyltin adducts are formed during incubation.

Effects of butyltin compounds on the incorporation of $\left|{ }^{14} \mathrm{C}\right|$-epinephrine into intact platelets

$\left|{ }^{14} \mathrm{C}\right|$-Epinephrine was incubated with PRP $\left(3.0 \times 10^{5}\right.$ cells $\left./ \mu 1\right)$ pretreated with inorganic tin $\left(\mathrm{SnCl}_{4}\right)$ or butyltin compounds at $37^{\circ} \mathrm{C}$ for $60 \mathrm{sec}$. After 5 min centrifugation, the incorporation of $\left|{ }^{14} \mathrm{C}\right|$-epinephrine into platelets was determined. Specific $\left|{ }^{14} \mathrm{C}\right|$-epinephrine incorporation was defined as total minus non-specific incorporation. As can be seen in Table 2, tributyltin $\left(>1 \times 10^{-7} \mathrm{M}\right)$ and dibutyltin $\left(>1 \times 10^{-5} \mathrm{M}\right)$ significantly inhibited the incorporation of $\left|{ }^{14} \mathrm{C}\right|-$

Table 2. Effects of tin compounds on the incorporation of $\left|{ }^{14} \mathrm{C}\right|$-epinephrine into intact human platelets

\begin{tabular}{lccc}
\hline & $\begin{array}{c}\text { Final concentration } \\
(\mathrm{M})\end{array}$ & $1 \mu \mathrm{M}$ & $3 \mu \mathrm{M}$ \\
\hline & $1 \times 10^{-11}$ & $78.7 \pm 3.67$ & $206 \pm 20.0$ \\
Tributyltin chloride & $1 \times 10^{-9}$ & $63.4 \pm 8.00$ & $186 \pm 24.7$ \\
& $1 \times 10^{-7}$ & $56.2 \pm 2.80^{*}$ & $163 \pm 11.7^{*}$ \\
& $1 \times 10^{-5}$ & $51.0 \pm 3.73^{*}$ & $140 \pm 21.0^{*}$ \\
\hline Dibutyltin dichloride & $1 \times 10^{-11}$ & $80.0 \pm 5.07$ & $222 \pm 28.9$ \\
& $1 \times 10^{-9}$ & $70.7 \pm 8.00$ & $211 \pm 12.7$ \\
& $1 \times 10^{-7}$ & $64.0 \pm 10.0$ & $182 \pm 14.0$ \\
& $1 \times 10^{-5}$ & $52.3 \pm 7.00$ & $176 \pm 10.0^{*}$ \\
\hline Monobutyltin trichloride & $1 \times 10^{-11}$ & $89.2 \pm 4.00$ & $236 \pm 20.5$ \\
& $1 \times 10^{-9}$ & $90.3 \pm 5.25$ & $244 \pm 19.0$ \\
& $1 \times 10^{-7}$ & $82.5 \pm 2.11$ & $233 \pm 13.4$ \\
\hline Tin (IV) chloride & $1 \times 10^{-5}$ & $74.1 \pm 4.08$ & $218 \pm 21.1$ \\
\hline Control & $1 \times 10^{-5}$ & $89.4 \pm 3.40$ & $241 \pm 12.1$ \\
\hline
\end{tabular}

The specific $\left[{ }^{14} \mathrm{C}\right]$-epinephrine incorporation is expressed as radioactivity $\left(\mathrm{dpm} \times 10^{-3}\right)$ per $10^{8}$ platelets. Values indicate the mean \pm S.D. of three experiments in PRP preincubated for $15 \mathrm{~min}$ with butyltin compounds and inorganic tin $\left(\mathrm{SnCl}_{4}\right)$. Controls were preincubated with $0.01 \%$ ethanol solution.

$* \mathrm{p}<0.01$, as compared with control. 
epinephrine $(1 \mu \mathrm{M}$ and $3 \mu \mathrm{M})$ into human intact platelets. Although a decreasing tendency of incorporation was seen in platelets pretreated with monobutyltin, there was no significant decrease even at $1 \times 10^{-5} \mathrm{M}$. In addition, inorganic tin $\left(\mathrm{SnCl}_{4}\right)$ did not show any inhibitory effects on the incorporations of $\left|{ }^{14} \mathrm{C}\right|-$ epinephrine into platelets even at $1 \times 10^{-5} \mathrm{M}$.

Inhibition of $\left|{ }^{3} \mathrm{H}\right|-D H E C$ binding by butyltin compounds

Specific bindings of $\left|{ }^{3} \mathrm{H}\right|$-DHEC $(0.5$ to $40 \mu \mathrm{M})$ to intact platelets at $37^{\circ} \mathrm{C}$ reached equilibrium within approximately $30 \mathrm{~min}$. Therefore, all equilibrium binding studies were carried out for $30 \mathrm{~min}$. Gel-filtered platelets were used in these experiments. Binding of $\left|{ }^{3} \mathrm{H}\right|$-DHEC to platelets was apparently inhibited by butyltin compounds (Fig. 3). Binding of $\left|{ }^{3} \mathrm{H}\right|$-DHEC to platelets pretreated with monobutyltin was saturable with increasing concentration of the ligand while binding of $\left|{ }^{3} \mathrm{H}\right|$-DHEC to platelets pretreated with di-, and tributyltin compounds did not reach plateau levels of binding even at a ligand concentration

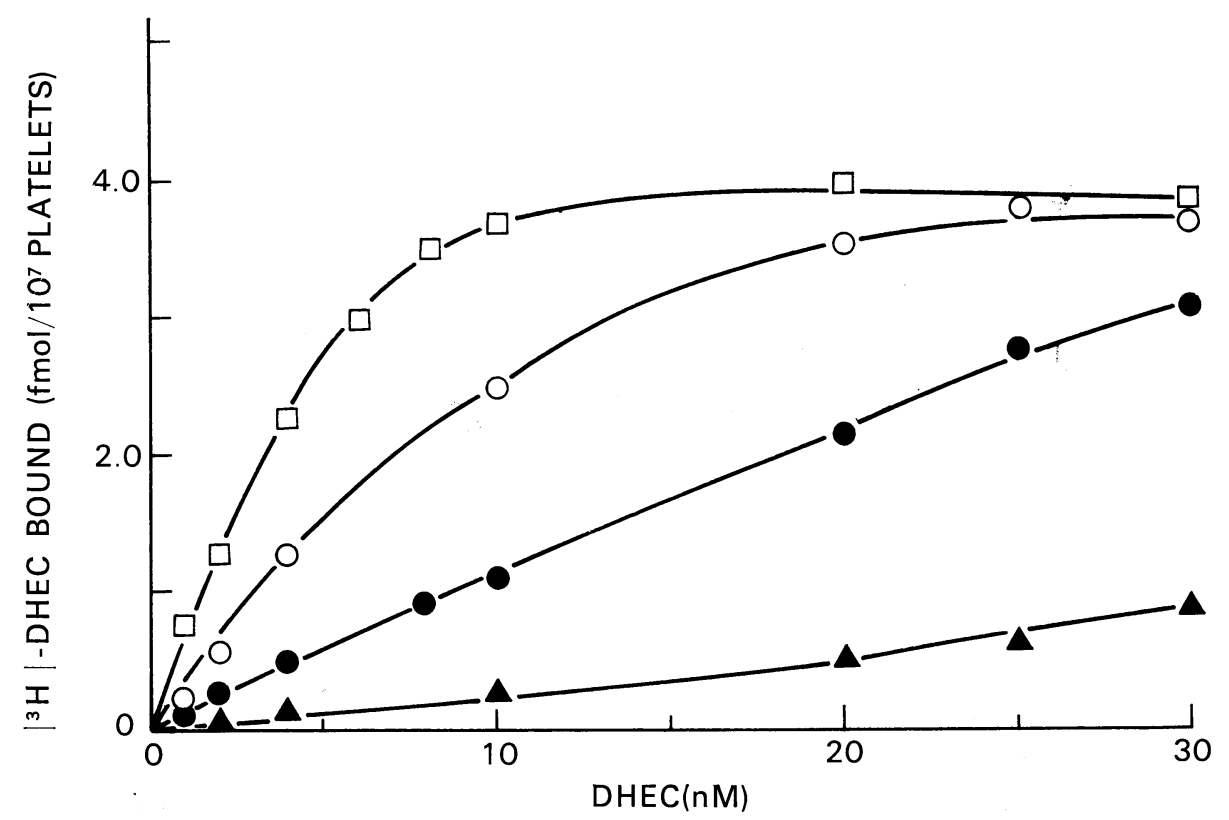

Fig. 3. The inhibition of $\left|{ }^{3} \mathrm{H}\right|-\mathrm{DHEC}$ binding to platelets by butyltin compounds.

$\left|{ }^{3} \mathrm{H}\right|$-DHEC was incubated with gel-filtered platelets pretreated with butyltin compounds $(1 \mu \mathrm{M})$ and a control $\left(0.01 \%\right.$ ethanol) for $30 \mathrm{~min}$ at $37^{\circ} \mathrm{C}$. The binding of $\left.\right|^{3} \mathrm{H} \mid$-DHEC to platelets is expressed as specific binding of DHEC per $10^{7}$ platelets.

$\square:$ Control

$O:$ Monobutyltin trichloride

0: Dibutyltin dichloride

$\Delta$ : Tributyltin chloride 
of $30 \mu \mathrm{M}$. These results, however, seem to agree with those suggesting that epinephrine itself has a counteractive effect against the inhibitory action of butyltin compounds (Fig. 2).

\section{Effects of tributyltin compounds on arachidonate metabolism}

To determine the effects of butyltin compounds on stimulus-induced arachidonate metabolism, tributyltin was selected for this experiment in view of its powerful inhibitory activity on platelet aggregation as shown in Fig. 1. Tributyltin did not have any effect on collagen-induced arachidonate metabolism (Fig. 4). Epinephrine-induced formation of arachidonate metabolites was not visualized by autoradiography because of low radioactivity. Therefore, the spots were visualized by iodide staining, and the radioactivity was determined by liquid scintillation counting. As can be seen in Table 3, a significant decrease in all the determined arachidonate metabolites was detected in tributyltin-pretreated platelets as compared with the control. These results suggest not only that tributyltin, one of the most powerful inhibitors of epinephrine-induced aggregation, does not

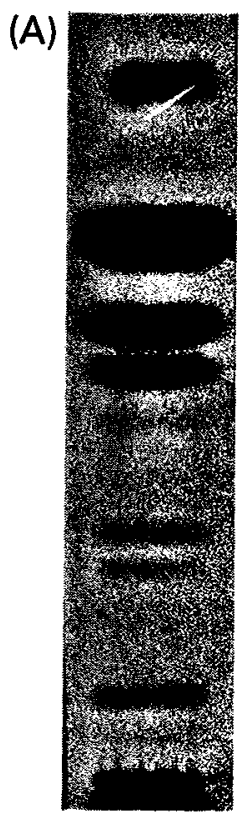

(B)

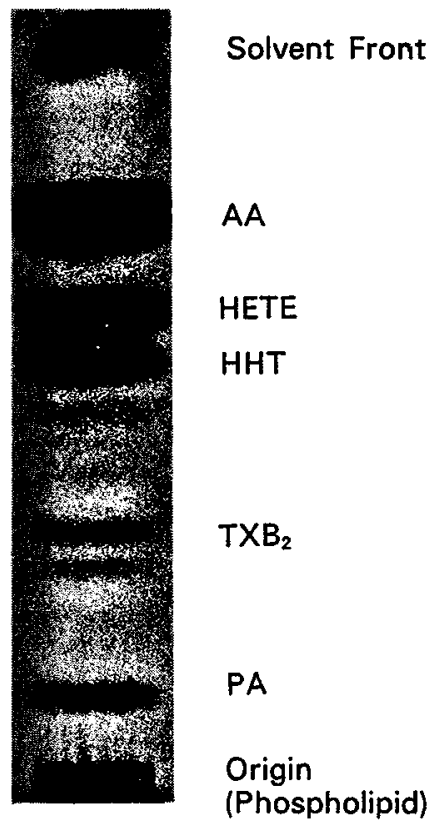

Fig. 4. Thin-layer chromatographic separation of radioactive phosphatidic acid, arachidonate and its metabolites.

Human platelets were prelabelled with ${ }^{14} \mathrm{C} \mid$-arachidonic acid and incubated with (A) $0.01 \%$ ethanol (control) or (B) tributyltin $\left(1 \times 10^{-5} \mathrm{M}\right)$ for $15 \mathrm{~min}$ at $37^{\circ} \mathrm{C}$ and then exposed to $2 \mu \mathrm{g} / \mathrm{m} l$ collagen. Radioactive spots were visualized by autoradiography.

Abbreviations: PA, phosphatidic acid; $\mathrm{TXB}_{2}$, thromboxane $\mathrm{B}_{2}$; HHT, 12-L-hydroxy-5, 8, 10-heptadecatrienoic acid; HETE, 12-L-hydroxy -5, 8, 10, 14-eicosatetraenoic acid; AA, arachidonic acid. 
Table 3. Effects of tributyltin on epinephrine-induced formation of arachidonate metabolites

\begin{tabular}{lccr}
\hline & \multicolumn{3}{c}{ Arachidonate metabolites (cpm) } \\
& TXB $_{2}$ & HHT & HETE \\
\hline Tributyltin chloride $\left(1 \times 10^{-5} \mathrm{M}\right)$ & $158 \pm 15^{*}$ & $169 \pm 18^{*}$ & $366 \pm 27^{*}$ \\
Control & $511 \pm 44$ & $605 \pm 51$ & $1801 \pm 200$ \\
\hline
\end{tabular}

Human platelets prelabeled with $\left[{ }^{14} \mathrm{C}\right]$-arachidonic acid were incubated with $0.01 \%$ ethanol (control) or tributyltin chloride $\left(1 \times 10^{-5} \mathrm{M}\right)$ for $15 \mathrm{~min}$ at $37^{\circ} \mathrm{C}$ and then exposed to $2 \mu \mathrm{M}$ epinephrine. Radioactive spots were visualized by iodide staining, and the radioactivity was determined using a liquid scintillation counter.

* $\mathrm{p}<0.01$, as compared with control.

influence arachidonate metabolism, but also that this compound inhibits arachidonate release from the platelet membrane only when epinephrine is used as a stimulant.

\section{Discussion}

The results of the present study demonstrate that mono-, di-, and tributyltin inhibit epinephrine-induced human platelet aggregation in vitro. It is interesting to note that these butyltin compounds did not inhibit the platelet aggregation induced by other stimuli (ADP, arachidonate, and collagen) (Table 1). Butyltin compounds, furthermore, apparently inhibited the binding of $\left|{ }^{3} \mathrm{H}\right|-$ DHEC, a potent alpha-adrenergic antagonist, to human platelets (Fig. 3). This result indicates that butyltin compounds inhibit the binding of epinephrine, an alpha-adrenergic agonist, to alpha-adrenergic receptors of platelets, because it has been established that DHEC competes for alpha-adrenergic agonists including epinephrine. ${ }^{15,16)}$ In accordance with this result, dibutyltin $\left(>1 \times 10^{-5} \mathrm{M}\right)$ and tributyltin $\left(>1 \times 10^{-7} \mathrm{M}\right)$ significantly inhibited the incorporation of $\left|{ }^{14} \mathrm{C}\right|-$ epinephrine into intact platelets while no significant decrease of $\left|{ }^{14} \mathrm{C}\right|$-epinephrine incorporation was observed in platelets pretreated with monobutyltin (Table 2). These results indicate that butyltin compounds are potent inhibitors of epinephrine-platelet binding, and also that the inhibition of epinephrine-induced aggregation by butyltin compounds is due to the inhibitory actions of these compounds on the binding of epinephrine to platelet membrane. On the other hand, inhibitory actions of butyltin on $\left|{ }^{3} \mathrm{H}\right|$-DHEC binding and epinephrine-induced aggregation were counteracted by overdoses of $\left|{ }^{3} \mathrm{H}\right|$-DHEC or epinephrine (Figs. 2 and 3 ). These results might suggest that butyltin compounds are potent competitive inhibitors of the alpha-adrenergic receptor, because there was no evidence that butyltin compounds destroy epinephrine or that butyltin compoundepinephrine adducts are formed during incubation.

It is generally accepted that metabolites of arachidonic acid are important for platelet function. In the results obtained from this study, tributyltin, the 
most powerful inhibitor of epinephrine- induced aggregation among the butyltin compounds tested, did not show any inhibitory effects on collagen-induced arachidonate metabolites (Fig. 4). However, tributyltin did inhibit the production of arachidonate metabolites by epinephrine (Table 3 ). These results suggest that butyltin compounds do not affect the metabolism of arachidonic acid, and that arachidonate release from platelet membrane lipids is inhibited only when platelets are stimulated by epinephrine. These results are compatible with the idea that butyltin compounds are inhibitors of the alpha-adrenergic receptor.

It has been reported that organotin compounds including tributyltin affect the tissue catecholamine levels in animals in vivo. Robinson ${ }^{18)}$ reported that heart epinephrine levels are increased by di-, and tributyltin in rats while adrenal epinephrine and norepinephrine levels are significantly reduced. In his report, the above author mentioned that the increase of epinephrine and norepinephrine in heart after administration of these organotin compounds tends to parallel the release of these catecholamines from the adrenals. This evidence may suggest that butyltin compounds produce a catecholamine-resistant state by inhibiting the binding of catecholamine to tissues, as the results of our experiments indicate that butyltin compounds are alpha-adrenergic antagonists.

Recent studies in our laboratory have shown that organotin compounds inhibit the stimulus-reaction system of platelets, ${ }^{10)}$ granulocytes $^{11,12)}$ and pancreatic islets. $^{7-9)}$ In the present experiment, we have shown that butyltin compounds inhibit epinephrine-induced aggregation by acting on the membrane alpha-adrenergic receptor. Other organotin compounds such as triphenyltin and tricyclohexyltin did not have any effects on human platelet aggregation induced by epinephrine (unpublished data). These findings suggest that butyltin compounds possess a special characteristic in their mode of action on mammalian cells. In this connection, the inhibition of epinephrine-induced aggregation by butyltin compounds might be useful as an index of exposure to these compounds in human subjects.

\section{ACKNOWLEDGEMENT}

This work was supported in part by a Grant-in-Aid for Scientific Research (No. 60440039) from the Ministry of Education, Science and Culture of Japan. We are deeply indebted to Dr. Shigeo Manabe for preparing this manuscript. We are also grateful to Drs. Yasuhisa Kitagawa and Shinsuke Ishikawa for their helpful discussion. The excellent secretarial assistance of Ms. Mayumi Manabe is gratefully acknowledged. 


\section{REFERENCES}

1) Engelherat, J. E. and Sheldon, A. E. (1975). Organotin anti-foulants: their toxicology and environmental impact, In Guidelines for Safe Handling in Chemical and Paint Manufacturing and Removal, 15th Annual Marine Coating Conference, Point Clear, AL.

2) Zuckerman, J. J. Reisdorf, R. P., Ellis III, H. V., Wilkinson, R. R. (1978). Organotins in biology and the environment. "ACS symposium series No. 82 Organometals and organometalloids: Occurrence and fate in the environment" (Edited by Brinckman, F. E. and Bellama, J. M.) American Chemical Society, Washingtn D.C.

3) Aldrige, W. N., Street, B. W. and Skilleter, D. N. (1977). Oxidative phosphorylation: halide-dependent and halide-independent effects of triorganotin and triorganolead compounds on mitochondrial function, Biochem. J., 168, 353 .

4) Magee, P. N., Stoner, H. R. and Barnes, J. B. (1957). The experimental production of edema in the central nervous system of the rat by triethyltin compounds, J. Pathol. Bacteriol., 73, 107.

5) Seinen, W., Vos, J. G. and Hooykaas, H. (1979): Lymphocytotoxicity and immunosuppression by organotin compounds: suppression of graft-vesus-host reactivity, blast transformation, and E-rosette formation by di-n-butyltin dichloride and di-n-octyltin dichloride, Immunopharmacology, 1, 343.

6) Arakawa, Y., Yamazaki, N., Yu, T. H. and Nagahashi, M. (1980). Effects of organotin compounds on the immune functions: Atrophy of thymus by di-n-butyltin dichloride, $J$. Toxicol. Sci., 5, 258.

7) Manabe, S. and Wada, O. (1981). TPTF induced diabetic lipemia by inhibiting insulin secretion from morphologically intact rabbit B-cell, Diabetes, 30, 1013.

8) Matsui, H., Wada, O., Manabe, S. and Ono, T. (1983). Effects of tricyclohexyltin hydroxide on carbohydrate and lipid metabolism in rabbits, Jpn. J. Ind. Health, 25, 10 (in Japanese).

9) Matsui, H., Wada, O., Manabe, S., Ono, T., Iwai, H. and Fujikura, T. (1982). Properties and mechanism of hyperlipidemia induced in rabbits by tributyltin fluoride, Jpn. J. Ind. Health, 24, 163 (in Japanese).

10) Manabe, S., Wada, O., Matsui, H., Takada, M., Kobayashi, N. and Maekawa, T. (1983). Triphenyltin fluoride in vitro inhibition of rabit platelet collagen-induced aggregation and ATP secretion and blockade of arachidonic acid mobilization from membrane phospholipids, Biochem. Pharmacol., 32, 1627.

11) Arakawa, Y. and Wada, O. (1984). Inhibition of neutrophil chemotaxis by organotin compounds, Biochem. Biophys. Res. Comm., 123, 543.

12) Matsui, H., Wada, O., Ushijima, Y. and Akuzawa, Y. (1983). Triphenyltin chloride inhibits superoxide production by human neutrophils stimulated with a surface active agent, FEBS Lett., 164, 251.

13) Feinman, R. D., Lubowsky, J., Charo, I. and Zabinski, M. P. (1977). A new instrument for simultaneous measurement of secretion and aggregation, J. Lab. Clin. Med., 90, 125.

14) Tangen, O., Bergman, H. J. and Marfey, P. (1971). A new technique for separation of blood platelets from plasma, Thrombos. Diathes. Haemorrh., $25,2$.

15) Alexander, R. W., Cooper, B. and Handin, R. I. (1978). Characterization of the human platelet alpha-adrenergic receptor, J. Clin. Invest., 61, 1136.

16) Newman K. D., Williams, L. T., Bishopric, W. N. and Lefknowitz, R. J. (1978). Identification of alpha-adrenergic receptors in human platelets $\left|{ }^{3} \mathrm{H}\right|$ dihydroergocryptine binding, J. Clin. Invest., 61, 395.

17) Billah, M. M., Lapetina, E. G. and Cuatrecasas, P. (1979). Phosphatidylinositol-specific phospholipase $\mathrm{C}$ of platelets: Association with 1, 2-diacylglycerol-kinase and inhibition of cyclic AMP, Biochem. Biophys. Res. Commun., 90, 92. 
18) Robinson, I. M. (1968). Effects of some organotin compounds on tissue amine levels in rats, Fd. Cosmet. Toxicol., 7, 47. 